\title{
Reliability of commercial triple junction concentrator solar cells under real climatic conditions and its influence on electricity cost
}

Manuel Vazquez

, Julen Tamayo-Arriola , Vincenzo Orlando , Neftali Nuñez

Olga Alburquerque and Carlos Algora

\begin{abstract}
This paper proposes a methodology for assessing the concentrator solar cell reliability in a real application for a given location provided the results from accelerated life tests. We have applied this methodology for the evaluation of warranty times of commercial triple junction solar cells operating inside real concentrator modules in Golden (Colorado, USA), Madrid (Spain) and Tucson (Arizona, USA) for the period 2012-2015. Warranty times in Golden and Madrid, namely, 68 and 31 years, respectively, for the analysed period, indicate the robustness of commercial triple junction solar cells. Nevertheless, the warranty time of 15 years for Tucson suggests the need of improvement in the heat extraction of the solar cell within the concentrator module. Therefore, the influence of the location on the reliability of concentrator solar cells is huge, and it has no sense to supply general reliability values for a given concentrator product. The influence of these warranty times for the three locations on the levelised cost of electricity has been analysed. Cost of $€ \mathrm{c} 10-12 / \mathrm{kWh}$ can be achieved nowadays, while after $1 \mathrm{GW}_{\mathrm{n}}$ cumulative installed power, a dramatic reduction to levels of $€_{\mathrm{c}} 2-3 / \mathrm{kWh}$ is achievable.
\end{abstract}

KEYWORDS

CPV; LCOE; reliability; real application; location influence

\section{INTRODUCTION}

During the last years, III-V solar cells have been widely used in concentrator photovoltaic (CPV) systems due to their high demonstrated efficiency $(40-42 \%$ for commercial triple junction, while $46 \%$ and $44.4 \%$ at laboratory scale for four and triple junction cells respectively) [1] that allows a reduction in installation size and costs [2,3]. In order to have a wide deployment of CPV systems, one important pending issue is to demonstrate long-term reliability on field. After more than 10 years of experience, a big amount of progress has accomplished by $\mathrm{CPV}$ in such a way that several plants are exhibiting an almost negligible degradation after years of operation [4]. Well-developed commercial CPV modules are nowadays very reliable, and they have a negligible impact on the unreliability of modern CPV plants. However, the historic evolution of CPV modules is plenty of different types of failures, such as thermal runaway, ground faults and deficient seal [5], whose appraisal and comprehension of the physical causes behind have allowed their control and, eventually, their suppression.

Despite this improvement and good performance exhibited by most modern CPV plants and modules, their deployment around the world is not widespread enough and their reliability track record on field is far from the 30-year target. Therefore, accelerating ageing tests providing the long-term reliability are of great help.

A key difference between CPV and PV is the higher thermal stress experienced by CPV systems. The thermal stress suffered by the heart of the CPV systems, namely, the concentrator solar cells, is of particular interest. This stress, and therefore reliability, depends in an important way on the location where the CPV systems are placed. 
Climate affects both the performance and reliability of photovoltaic modules, and there are several works that analyse the influence of atmospheric conditions, location, etc. on the performance of conventional solar modules [6-8]. However, to the best of our knowledge, there is no work that analyses neither the influence of climatic location in the reliability of CPV solar cells nor its influence in the LCOE (levelised cost of electricity).

It is well known that temperature affects reliability. Most of failure mechanisms in a device are accelerated by temperature, and therefore, life parameters of a product are accelerated by temperature. In the particular case of CPV solar cells operating under real conditions, temperature is an uncontrolled parameter that depends on several atmospheric parameters such as ambient temperature, irradiance and wind, which vary with climatic location and thermal management in CPV design.

In previous works, we have calculated the reliability parameters of CPV solar cells by means of temperature accelerated life test (ALT) [9-11]. From these ALTs, the reliability function, $R(t)$, the probability of failure as function of time, etc. were determined by assuming that the CPV solar cells were at a fixed temperature during a specific number of hours per day, namely, $80{ }^{\circ} \mathrm{C}$ during $5 \mathrm{~h}$ per day.

However, the consideration of stable working conditions in CPV solar cells is far from reality because there are many parameters (impinging irradiance, ambient temperature, wind speed, etc.) that vary along the day, year and location. These environmental parameters dramatically influence the solar cell temperature, making difficult to obtain the reliability results under real operation conditions at a given location. This information is key in order to estimate the real lifetime of the CPV solar cells.

Accordingly, in this paper, we face that problem by proposing a methodology that assesses the solar cell reliability parameters in a real application for a given location from results obtained from ALTs. The methodology is applied to the case studies of Golden (CO, USA) [12], Madrid (Spain) and Tucson (AZ, USA) [13]. As lifetime of CPV cells (and systems) directly impacts LCOE, an analysis in those three locations is also carried out.

\section{MODEL DESCRIPTION}

The steps to extrapolate the reliability data obtained in an ALT for an arbitrary temperature to the real operation conditions at a given location are the following: (i) to evaluate the solar cell temperature at any time (instantaneous temperature) for a specific location and year and (ii) to evaluate the solar cell reliability for a specific location and year, using both the solar cell instantaneous temperature evaluated in the previous step and the reliability parameters obtained from a temperature ALT, assuming a specific reference solar cell temperature for reliability purposes [10].

\subsection{Determination of the solar cell temperature}

There are several models for the determination of the solar cell temperature from atmospheric parameters $[7,14,15]$. In this work, solar cell temperature is determined by means of a model based on an equivalent thermal circuit that was evaluated in the field for the same type of solar cells used in this work [16].

The simplified equivalent thermal circuit of a CPV module can be described by two series connected thermal resistances, $R_{\text {th }}$ c $\_\mathrm{m}$ and $R_{\text {th }} \mathrm{m} \_\mathrm{a}_{\text {a }}$ (Figure 1). The two thermal resistances relate three temperatures: $R_{\mathrm{th}} \quad \mathrm{c}_{-} \mathrm{m}$ relates temperatures between solar cell and module (measured under the cell in the rear side of the module), and $R_{\text {th }}$ m_a relates temperatures between module and ambient. In this model, we assume that $R_{\text {th }}$ c_m is not affected by wind because all the elements that affect $R_{\text {th c_m }}$ are enclosed inside the CPV module and, on the other hand, the elements that affect $R_{\text {th m } \_ \text {a }}$ are outside

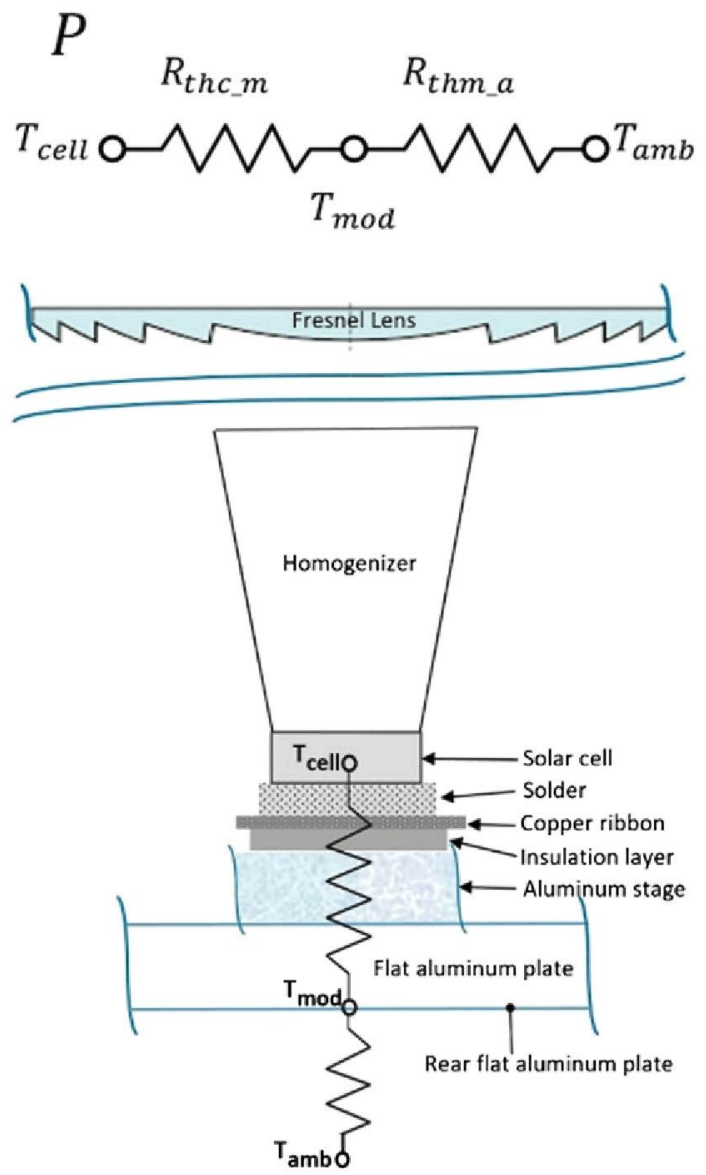

Figure 1. Equivalent thermal circuit of the analysed concentrator photovoltaic module. 
the CPV module, and therefore, $R_{\text {th }}$ ma is highly dependent on wind.

In the thermal circuit model (Figure 1), the temperature increment depends on both the thermal resistances and the power dissipated by means of the following equations:

$$
\begin{aligned}
& T_{\text {cell }}-T_{\text {mod }}=P \cdot R_{\text {th } \mathrm{c} \_\mathrm{m}} \\
& T_{\text {mod }}-T_{\text {amb }}=P \cdot R_{\text {th } \mathrm{m}_{-} \mathrm{a}}
\end{aligned}
$$

where the heat power $(P)$ dissipated in the solar cell with an area $(A)$ is related to the impinging irradiance (also called direct normal irradiance, DNI), concentration $(C)$ and optical and solar cell efficiencies, $\eta_{\text {op }}$ and $\eta_{\text {cell }}$ :

$$
P=\eta_{\mathrm{op}} \cdot C \cdot \mathrm{DNI} \cdot A \cdot\left(1-\eta_{\mathrm{cel} 1}\right)
$$

Therefore, the instantaneous temperature of the solar cell can be determined if the power dissipated in the solar cell, both thermal resistances and instantaneous atmospheric data (namely, ambient temperature $\left(T_{\mathrm{amb}}\right)$, $D N I$ and wind speed), are known:

$$
\begin{aligned}
T_{\text {cell }}= & T_{\mathrm{amb}}+\eta_{\mathrm{op}} \cdot C \cdot \mathrm{DNI} \cdot A \cdot\left(1-\eta_{\text {cell }}\right) \cdot R_{\mathrm{th} \mathrm{c \_ m}}+ \\
& +\eta_{\mathrm{op}} \cdot C \cdot \mathrm{DNI} \cdot A \cdot\left(1-\eta_{\text {cell }}\right) \cdot R_{\mathrm{th}} \mathrm{m}_{\mathrm{a}}
\end{aligned}
$$

In Eqn (3), there are parameters related only with the CPV module design ( $\eta_{\text {op }}, \eta_{\text {cell }}, A, C$ and $R_{\text {th }}$ c m $)$, parameters related with climatic conditions ( $T_{\mathrm{amb}}$ and DNI) and, finally, $R_{\text {th }} \mathrm{m}$ a that is related with both the CPV module design and the climatic conditions because $R_{\text {th } \mathrm{m} \_\mathrm{a}}$ is affected by wind speed as it will be shown in section 3 .

In this work, the model will be applied to a specific type of solar cell implemented in a CPV module, whose reliability and thermal behaviour have been analysed in previous papers $[10,16]$. In order to evaluate the solar cell instantaneous temperature, it is necessary to know both $R_{\text {th } \mathrm{m}_{\mathrm{a}} \mathrm{a}}$ and $R_{\text {th } \mathrm{c} \_\mathrm{m}}$ at the CPV module in field together with the atmospheric database of irradiance, ambient temperature and wind speed at the required location. This database must provide instant atmospheric values (not hourly, daily or monthly mean values) that allow us to determine the solar cell instantaneous temperature.

In this work, we use instantaneous meteorological database recorded every minute, and therefore, we assume that during that minute, the climatic parameters are stable. Three different locations suitable for CPV systems, namely, Madrid (Madrid, Spain), Golden (Colorado-USA) and Tucson (Arizona-USA), will be analysed.

\subsection{Determination of the solar cell reliability}

In this subsection, we will show how to extrapolate the reliability parameters from an ALT, assessed for a given solar cell temperature, to the real solar cell temperature. We assume that (i) the reliability parameters are accelerated by temperature and the obtained results follow an Arrhenius law [10,17] and (b) the activation energy, $E_{\mathrm{a}}$, has been evaluated previously in the same temperature ALT that has provided the solar cell reliability results.

In the proposed case study (detailed in section 3.1), the reliability parameters have been obtained for a reference temperature of $80^{\circ} \mathrm{C}[10]$. Therefore, it is possible to make a relationship between the time in real conditions at $T_{\text {cell }}$ and the time at $80^{\circ} \mathrm{C}$ by means of the Arrhenius law. This relationship is called acceleration factor of $T_{\text {cell }}$ with respect to $80^{\circ} \mathrm{C}, \mathrm{AF}_{\mathrm{cell} / 80}$ :

$$
\begin{aligned}
\mathrm{AF}_{\mathrm{Tcell} / 80} & =\frac{t_{\mathrm{T}_{\text {cell }}}}{t_{80}} \\
& =\exp \left[\frac{E_{\mathrm{a}}}{k} \cdot\left(\frac{1}{273.15+T_{\text {cell }}}-\frac{1}{273.15+80}\right)\right]
\end{aligned}
$$

As derived from Eqn (4), if solar cell temperature is lower than $80^{\circ} \mathrm{C}$, then AF will be lower than 1 , while if solar cell temperature is higher than $80^{\circ} \mathrm{C}$, then $\mathrm{AF}$ will be higher than 1. AF also depends on the activation energy $\left(E_{\mathrm{a}}\right)$ value obtained in the ALT. Figure 2 shows the impact of temperature for different activation energy values on AF.

In this reliability analysis, the following assumptions have been considered:

- Not only the solar cell temperature for thermally driven failure mechanisms but also the time that the solar cell is at that temperature are important. Therefore, the solar cell temperature for the whole year will be defined by a histogram representing the time intervals for which the solar cell is at different instantaneous temperatures [18].

- Temperature is the main environmental parameter defining the solar cell reliability. This assumption is very common for many electronic and optoelectronic devices [19-22].

- Only the solar cell operation period is considered (namely, when DNI is higher than $20 \mathrm{~W} / \mathrm{m}^{2}$ ). This

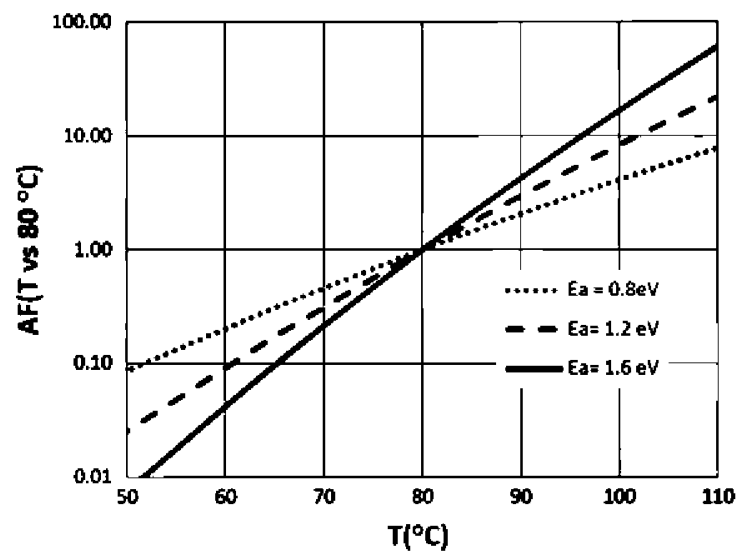

Figure 2. Acceleration factor, AF (T referred to $\left.80^{\circ} \mathrm{C}\right)$, for three different $E_{\mathrm{a}}$. 
is a common practice in reliability because it is widely accepted that devices that are not working have much higher reliability than devices that are working [23].

Taking into account the hours per year at each interval $\left(1{ }^{\circ} \mathrm{C}\right.$ width $)$ of solar cell temperature and the AF of this temperature interval with respect to $80^{\circ} \mathrm{C}$, it is possible to evaluate the equivalent time at $80^{\circ} \mathrm{C}$ for each interval of temperature of the histogram. Therefore, a new histogram of equivalent time at $80^{\circ} \mathrm{C}$ can be calculated:

$$
t_{\mathrm{eq}, 80^{\circ} \mathrm{Ci}}=A F_{\mathrm{T}_{\text {celli } / 80}} \cdot t_{\text {celli }}
$$

being $t_{\text {celli }}$ the real time per year that the solar cell is in the interval between $T_{\text {cell }}=T_{\text {celli }}-0.5$ and $T_{\text {cell }}=T_{\text {celli }}+0.5$. $A F_{\text {Tcelli/80 }}$ is the AF of $T=T_{\text {celli }}$ with respect to $80{ }^{\circ} \mathrm{C}$ obtained from Figure 2 or Eqn (4). This new histogram, where real times are modified by a multiplier factor that considers the acceleration factor due to the solar cell temperature with respect to $80^{\circ} \mathrm{C}$, is called solar cell temperature histogram with equivalent time at $80{ }^{\circ} \mathrm{C}$. These times are the equivalent times at $80{ }^{\circ} \mathrm{C}$ from the reliability point of view.

By adding the equivalent time at $80{ }^{\circ} \mathrm{C}$ for all the intervals of temperature in this new histogram, the yearly equivalent time at $80^{\circ} \mathrm{C}$ is obtained:

$$
t_{\text {equivalent } 80^{\circ} \mathrm{C}}=\sum_{i=T_{\text {cell__min }}}^{T_{\text {cell__max }}} A F_{\mathrm{T}_{\text {cellit } / 80}} \cdot t_{\text {celli }}
$$

This yearly equivalent time at $80{ }^{\circ} \mathrm{C}$ value, which depends on solar cell temperature and $E_{\mathrm{a}}$, can be compared with the reliability results at $80{ }^{\circ} \mathrm{C}$ obtained in the temperature ALT. Therefore, reliability parameters for a given solar cell type and location can be assessed. In section 3 , this procedure will be applied to the solar cell type whose temperature ALT reliability has been analysed in previous works [10].

\section{RESULTS}

Because the final results depend on the selected CPV module, we have applied the model of section 2 to a real application in order to show the model's functionalities. The most relevant parameters of the real application are as follows:

(1) Characteristics of the CPV module:

- The CPV module implements commercial latticematched GaInP/GaInAs/Ge triple-junction solar cells with an active area of $49 \mathrm{~mm}^{2}$ solar cell $(7 \times 7 \mathrm{~mm})$. The temperature ALT of this solar cell type has been carried out in a previous work [10].

- Thermal resistances related to the solar cells in the CPV module have been assessed from a previous work [16]. $R_{\text {th c_m }}=1.476^{\circ} \mathrm{C} / \mathrm{W}$, which does not depend on wind speed as it has been explained in section 2 . On the other hand, $R_{\text {th m_a }}$ decreases with wind speed and it has been fitted to a linear relationship, $R_{\mathrm{th} \mathrm{m}_{-} \mathrm{a}}\left(\frac{{ }^{\circ} \mathrm{C}}{\mathrm{W}}\right)=1.783-0.102 \cdot \mathrm{v}_{\text {wind }}$, being $v_{\text {wind }}$ the wind speed in $\mathrm{m} / \mathrm{s}$.

- Concentration ratio is 820 suns

- Solar cell efficiency is $35 \%$ at 820 suns.

- Optical efficiency is $85 \%$

(2) Reliability parameters of the solar cells under arbitrary typical conditions $(5 \mathrm{~h}$ per day at $T_{\text {cell }}=80^{\circ} \mathrm{C}$ ) determined in Refs $[10,24]$ used to evaluate the reliability parameters in real conditions:

- The $E_{\mathrm{a}}$ of the main failure mechanism is $1.59 \mathrm{eV}$.

- The warranty time for $5 \%$ of failures at $T_{\text {cel } 1}=80^{\circ} \mathrm{C}$,

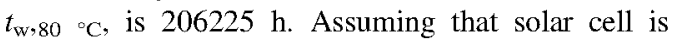
working at $80{ }^{\circ} \mathrm{C} 5 \mathrm{~h}$ per day, this warranty time results in 113 years [10].

\subsection{Case study: CPV module with triple junction commercial cells operating in Madrid (Spain) in 2014}

In order to illustrate the whole procedure described in section 2 when applied to the real application described in the preceding texts, we need to customise it for a given location and year. We have chosen Madrid in 2014, and we have used ambient temperature, DNI and wind speed as atmospheric parameters. Data have been obtained from the Instituto de Energía Solar meteorology station that measures the data each minute.

Firstly, we have discretised and summarised the atmospheric parameters for Madrid in 2014 in histograms that represent the time in a year that the atmospheric parameter is within an interval of the selected parameter; that is, for ambient temperature, the interval is $1{ }^{\circ} \mathrm{C}$, while for DNI $20 \mathrm{~W} / \mathrm{m}^{2}$ and for wind speed, the interval is $0.5 \mathrm{~m} / \mathrm{s}$. Figure 3 shows the wind speed, DNI and temperature histograms for Madrid in 2014.

Figure 3 (bottom) shows the histograms of the ambient temperature and the solar cell temperature calculated by following the model described in section 2.1 for Madrid in 2014 only when there is solar radiation. Obviously, these histograms will vary each year in each location; thus, an analysis of both influences will be presented in section 3.3.

Figure 3 (bottom) shows that the ambient temperature when there is solar radiation ranges from $-2{ }^{\circ} \mathrm{C}$ to $36{ }^{\circ} \mathrm{C}$, while solar cell temperature ranges from $0{ }^{\circ} \mathrm{C}$ to $102{ }^{\circ} \mathrm{C}$. Moreover, the solar cell temperature histogram exhibits higher values and a larger dispersion than ambient temperature. In fact, the cell temperature histogram is lefttailed and exhibits a mean of $66.9^{\circ} \mathrm{C}$, a median of $72.7^{\circ} \mathrm{C}$ and a mode of $78.5^{\circ} \mathrm{C}$. These values are slightly lower than the $80^{\circ} \mathrm{C}$ used in Ref. [10]. The impact of this difference will be analysed in section 3.3. 

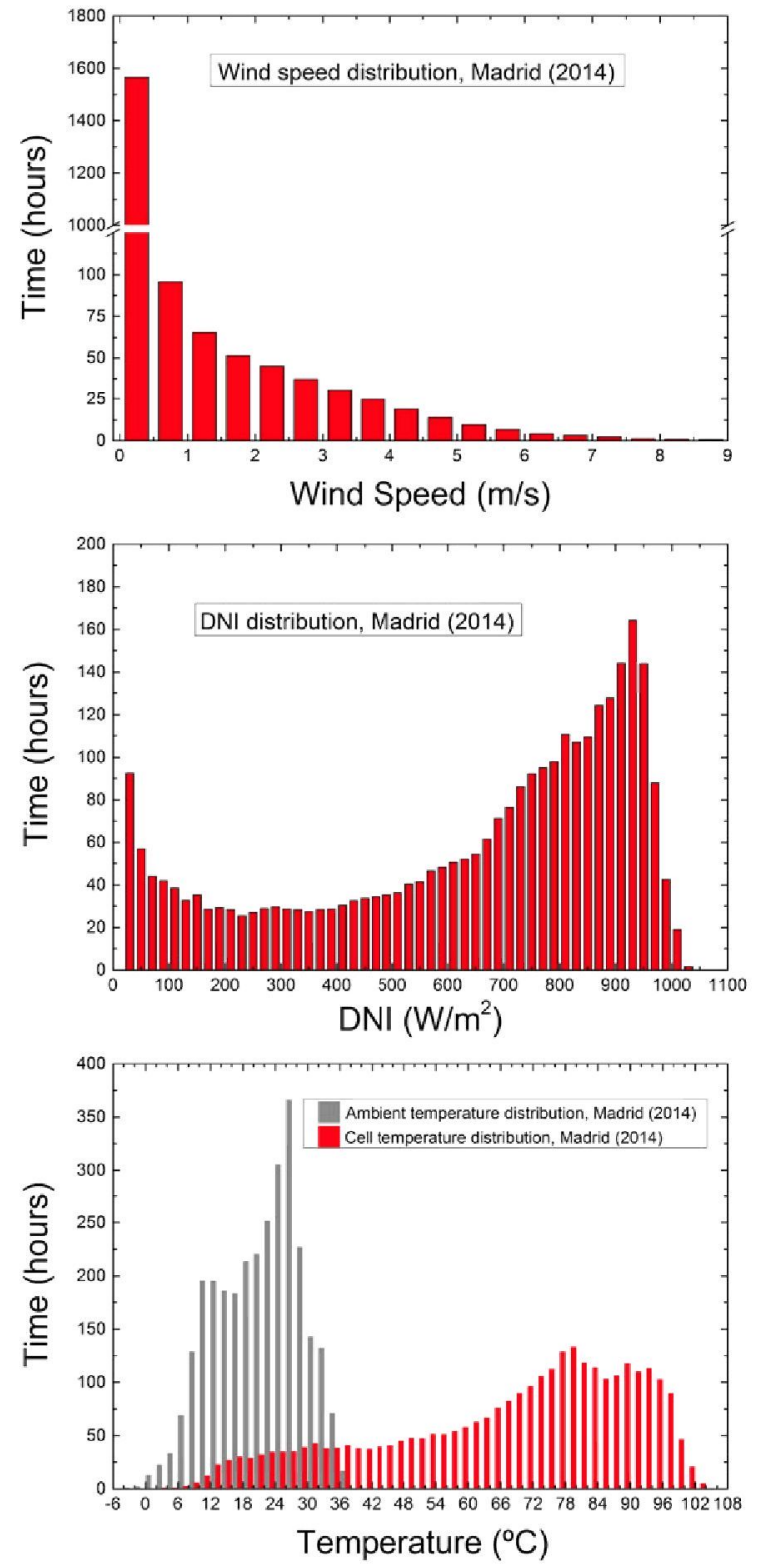

Figure 3. Wind speed (top), direct normal irradiation (centre) and ambient temperature and solar cell temperature (bottom) histograms for Madrid in 2014.

The solar cell temperature histogram gives us information about the real temperature the solar cell is. However, it is necessary to consider that, from the reliability point of view, the influence of one unit of time, that is, $1 \mathrm{~h}$, at high solar cell temperatures has much more influence in the life of the product than this same unit of time at low temperatures because of the influence of acceleration factor. Therefore, in order to achieve a reliability target, not only solar cell temperature must be considered but also the influence of solar cell temperature must be taken into account. How to assess the reliability parameters considering this influence is shown in the succeeding texts.

In order to determine the solar cell reliability parameters for Madrid in 2014 from the reliability parameters at $80^{\circ} \mathrm{C}$ obtained by means of ALT, it is necessary to take into account the $A F_{\mathrm{T}_{\text {cell }} / 80}$ for the different solar cell temperatures. By applying the acceleration factors at the different intervals of the solar cell histogram (Eqn. (5)), a new histogram results in Figure 4 with the equivalent time at $80^{\circ} \mathrm{C}$ for each temperature interval. As it can be seen in Figure 4 , the equivalent time at $80{ }^{\circ} \mathrm{C}$ for temperatures higher than $80^{\circ} \mathrm{C}$ is larger than real time because $\mathrm{AF}$ (Eqn (4)) is larger than 1, while for temperatures lower than $80^{\circ} \mathrm{C}$, the equivalent time at $80^{\circ} \mathrm{C}$ is lower than real time.

The new solar cell temperature histogram with equivalent time at $80^{\circ} \mathrm{C}$ shown in Figure 4 exhibits a more symmetric and narrowed distribution shifted to the higher solar cell temperature values and presents the following features:

(1) The total number of equivalent hours at $80^{\circ} \mathrm{C}$ in Madrid in 2014 for this solar cell was 5884 h that corresponds to $16.1 \mathrm{~h}$ per day. This value is three times larger than the arbitrary one of our previous work [10], namely, $5 \mathrm{~h}$ per day at $80^{\circ} \mathrm{C}$.

(2) The solar cell temperature histogram with equivalent time at $80^{\circ} \mathrm{C}$ is slightly left-tailed, and it has the following statistical parameters:

- The mean solar cell temperature with equivalent time at $80^{\circ} \mathrm{C}\left(T_{\text {eqMean }}\right)$ is $92.6{ }^{\circ} \mathrm{C}$. The equivalent time of working at this temperature is $972 \mathrm{~h}$ per year or $2.66 \mathrm{~h}$ per day.

- The median solar cell temperature with equivalent time at $80^{\circ} \mathrm{C}$ is $93.2{ }^{\circ} \mathrm{C}$.

- The mode solar cell temperature with equivalent time at $80{ }^{\circ} \mathrm{C}$ is $96.6^{\circ} \mathrm{C}$.

Therefore, the solar cell temperatures with the highest impact on reliability are those larger than $90^{\circ} \mathrm{C}$.

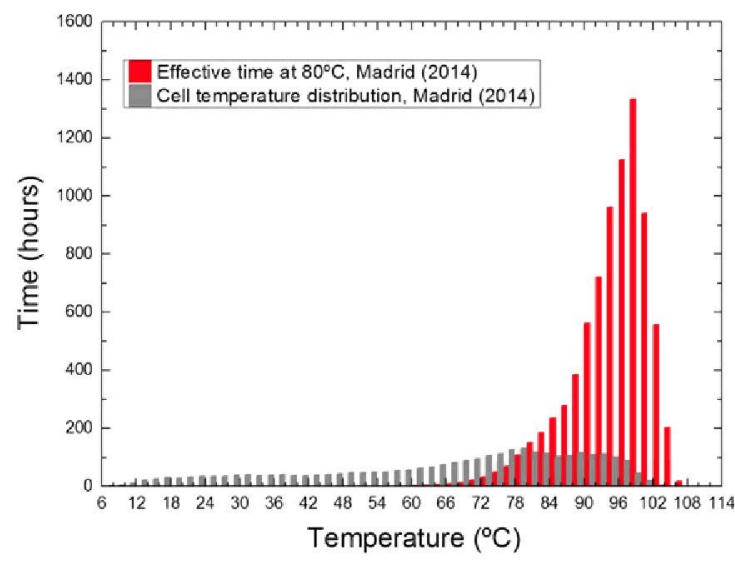

Figure 4. Histograms of the solar cell temperature for Madrid in 2014 (grey columns) and of the equivalent time at $80^{\circ} \mathrm{C}$ for the solar cell temperature Madrid 2014 (red columns). 
Now, we can start to use these results. Considering that the equivalent time at $80{ }^{\circ} \mathrm{C}$ in Madrid in 2014 was $5884 \mathrm{~h}$, the warranty time (for $5 \%$ of failures) of $206225 \mathrm{~h}$ at $80^{\circ} \mathrm{C}$ obtained from ALT [10] would mean 35 years. This value does not depend on the reference temperature value ( $80^{\circ} \mathrm{C}$ in this case) because if other reference temperatures were selected, the used $\mathrm{AF}$ to assess the warranty time $\left(206225 \mathrm{~h}\right.$ for $\left.80{ }^{\circ} \mathrm{C}\right)$ from temperature ALT will be the same than the AF used to assess the yearly equivalent time from the solar cell temperature histogram $\left(5884 \mathrm{~h}\right.$ for $\left.80^{\circ} \mathrm{C}\right)$ at the selected reference temperature. Therefore, if a higher reference temperature is selected, both the warranty time and the yearly equivalent time will be lower, but the ratio of them, which is the warranty time in years, will be the same. For instance, if we select $90^{\circ} \mathrm{C}$ as reference temperature in order to obtain the ALT results for the same solar cell, the warranty time at $90{ }^{\circ} \mathrm{C}$ is $48885 \mathrm{~h}$ and yearly equivalent time at $90{ }^{\circ} \mathrm{C}$ is $1395 \mathrm{~h}$, and therefore, warranty time will be again 35 years as can inferred from the following equation:

$$
\begin{aligned}
t_{\mathrm{w}}(\text { years }) & =\frac{t_{\mathrm{w}, 80^{\circ} \mathrm{C}}(\text { hours })}{t_{\mathrm{eq}, 80^{\circ} \mathrm{C}}(\text { hours } / \text { year })} \\
& =\frac{t_{\mathrm{w}, 90^{\circ} \mathrm{C}}(\text { hours }) \cdot \mathrm{AF}_{90^{\circ} \mathrm{C} / 80^{\circ} \mathrm{C}}}{t_{\mathrm{eq}, 90^{\circ} \mathrm{C}}(\text { hours } / \text { year }) \cdot \mathrm{AF}_{90^{\circ} \mathrm{C} / 80^{\circ} \mathrm{C}}}
\end{aligned}
$$

We have been focused in the calculation of the warranty time (for $5 \%$ of failures), but the model can be applied to any other reliability parameter calculated from the temperature ALT by means of the same procedure.

\subsection{Instant versus average meteorological data}

In order to evaluate the impact that instant atmospheric values have when assessing the reliability parameters, we have compared the warranty times evaluated from instantaneous values (measured each minute) or from average values (hourly and daily). Figure 5 shows the solar cell temperature for Madrid in 2014, considering both instantaneous and average data.

As it can be seen in Figure 5, the instantaneous solar cell temperature histogram is very similar to the hourly average solar cell temperature but very different to the daily average solar cell temperature histogram. As reliability parameters (i.e. warranty time) are greatly affected by high extreme solar cell temperature values, it is very important to consider instantaneous atmospheric data. In fact, average atmospheric data underestimate high solar cell temperature values, so the corresponding warranty times are higher than warranty times assessed for instantaneous values. For example, if daily average values are used, the warranty time is 63 years, while if the hourly average values are used, the warranty time is 40 years, instead of the warranty time of 35 years

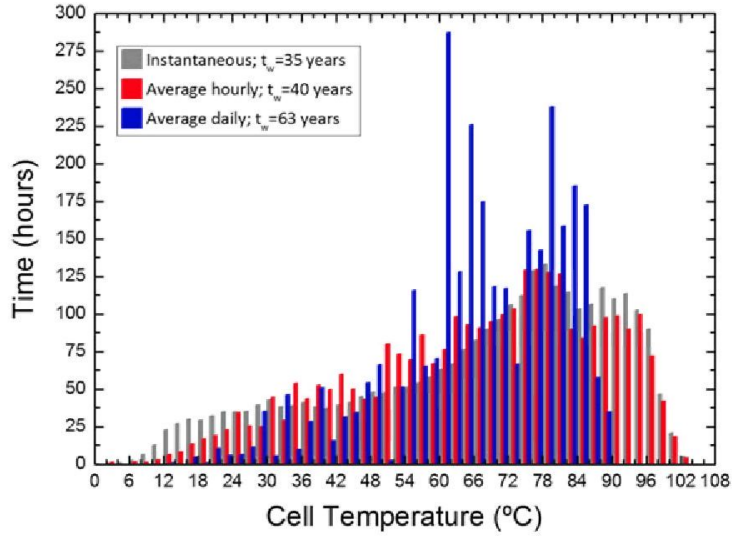

Figure 5. Solar cell temperature for instantaneous and average (hourly and daily) values for Madrid in 2014.

obtained by using instantaneous values. Therefore, in order to determine proper reliability values, it is necessary to use instantaneous (in the range of minutes) meteorological data.

\subsection{Influence of location and year}

As climatic parameters depend on the location and year, we have determined the solar cell temperature histograms with equivalent time at $80{ }^{\circ} \mathrm{C}$ for three locations, namely, Tucson (AZ,USA), Madrid (Spain) and Golden (CO, USA), and four years: 2012, 2013, 2014 and 2015 (Figure 6).

From those histograms, it is possible to determine the warranty time for the different locations and years that are gathered in Table I and summarised in Figure 7. This figure shows important differences in warranty times for the different locations and years. The results show that locations with higher mean solar cell temperature with equivalent time at $80{ }^{\circ} \mathrm{C}$ ( $\left.T_{\text {eqMean }}\right)$ have lower warranty times and that locations with similar annual DNI irradiation (Table I) and therefore similar expected annual photovoltaic electricity production, such as Madrid (Spain) and Golden (Colorado-USA), exhibit significant differences in warranty times. These differences are due to the impact of other atmospheric parameters such as ambient temperature and wind speed that affect the mean temperature at $80{ }^{\circ} \mathrm{C}$ equivalent temperature (Table I). The estimated warranty time taking into account the whole period 2012-2015 suggests excellent lifetimes for Golden and Madrid (68.4 and 31.1 years respectively).

However, the same type of commercial solar cell implemented in the same CPV module will have only 15.2 years of warranty time in Tucson for the same period of time. This result suggests the need of some improvement in the CPV cell or in the module heat extraction for proper operation in Tucson. Fortunately, this does not seem a hard 


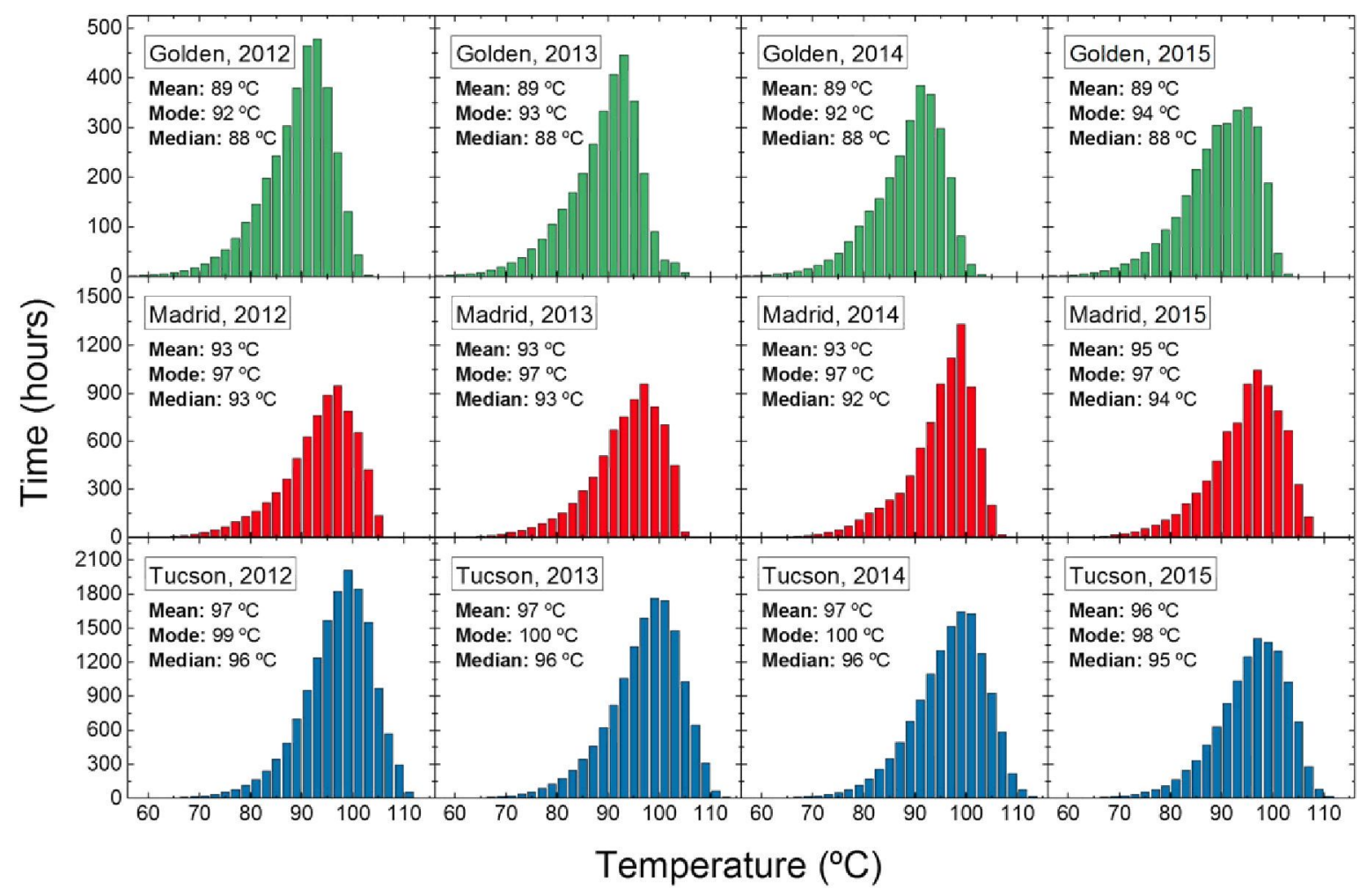

Figure 6. Histograms of solar cell temperature with equivalent time at $80^{\circ} \mathrm{C}$ for different locations and years. Notice the different scale for each location.

Table I. Warranty time for the analysed case (described in section 3) in three different locations and four years.

\begin{tabular}{|c|c|c|c|c|c|c|c|c|c|c|c|c|}
\hline & \multicolumn{3}{|c|}{2012} & \multicolumn{3}{|c|}{2013} & \multicolumn{3}{|c|}{2014} & \multicolumn{3}{|c|}{2015} \\
\hline & $\mathrm{t}_{\mathrm{w}}$ (years) & $\begin{array}{c}T_{\text {eqMean }} \\
\left({ }^{\circ} \mathrm{C}\right)\end{array}$ & $\begin{array}{c}\text { DNI } \\
\left(\mathrm{W} / \mathrm{m}^{2}\right)\end{array}$ & $\mathrm{t}_{\mathrm{w}}($ years $)$ & $\begin{array}{l}T_{\text {eqMiean }} \\
\left({ }^{\circ} \mathrm{C}\right)\end{array}$ & $\mathrm{DNI}\left(\mathrm{W} / \mathrm{m}^{2}\right)$ & $t_{\mathrm{w}}$ (years) & $\begin{array}{c}T_{\text {eqMean }} \\
\left({ }^{\circ} \mathrm{C}\right)\end{array}$ & $\begin{array}{c}\text { DNI } \\
\left(\mathrm{W} / \mathrm{m}^{2}\right)\end{array}$ & $\mathrm{t}_{\mathrm{w}}($ years $)$ & $\begin{array}{l}T_{\text {eqMean }} \\
\left({ }^{\circ} \mathrm{C}\right)\end{array}$ & $\begin{array}{c}\text { DNI } \\
\left(\mathrm{W} / \mathrm{m}^{2}\right)\end{array}$ \\
\hline $\begin{array}{c}\text { Golden } \\
\text { (CO, USA) }\end{array}$ & 60.9 & 89 & 654 & 67.7 & 89 & 671 & 75.4 & 89 & 656 & 70.9 & 89 & 658 \\
\hline $\begin{array}{l}\text { Madrid } \\
\text { (Spain) }\end{array}$ & 32.9 & 93 & 671 & 32.8 & 93 & 663 & 35.0 & 93 & 638 & $25.6^{*}$ & 95 & 659 \\
\hline $\begin{array}{c}\text { Tucson } \\
\left(A Z_{1} \text { USA }\right)\end{array}$ & 13.6 & 97 & 731 & 14.5 & 97 & 733 & 15.3 & 97 & 715 & $18.0^{* *}$ & 96 & 716 \\
\hline
\end{tabular}

Additional data as average solar cell temperature with equivalent time at $80^{\circ} \mathrm{C}$ and mean direct normal irradiation (DNI) are both calculated for daylight periods. As it can be seen, 2015 exhibited anomalous data. The origins of such results were the exceptional climatic conditions described above.

*Temperatures reached $40{ }^{\circ} \mathrm{C}$ in July for the first time on record (records date back to 1943) in Madrid': https://Mww. Climate.Gov/News-features/eventtracker/summer-heat-wave-arrives-europe.

** In June 2015, the Western Region Climate Center reported: 'Above normal precipitation fell in the southwest due to tropical storm remnants during the first half of the month and monsoon onset in the latter half'. Regarding Arizona, it was also said: 'June is the fifth wettest June in flagstaff since records began in 1893'. 'The southwest monsoon circulation reached Tucson, Arizona, during late June, a week earlier than usual'. https://www. Nodc. Noaa.Gov/ sotc/national/201506.

task because we have recently shown that the failure origin of these cells is related with the front metal grid and its external connection and not the semiconductor structure [25].

If the failure limit for warranty would increase from $5 \%$ to $10 \%$ of the solar cells, larger warranty times would be obtained (Table II) for the three locations. Therefore, we have shown that it is crucial to consider the location and its climatic characteristics (ambient temperature, wind speed and DNI) in order to properly determine the reliability parameters of a type of CPV solar cell implemented in a real CPV module. 


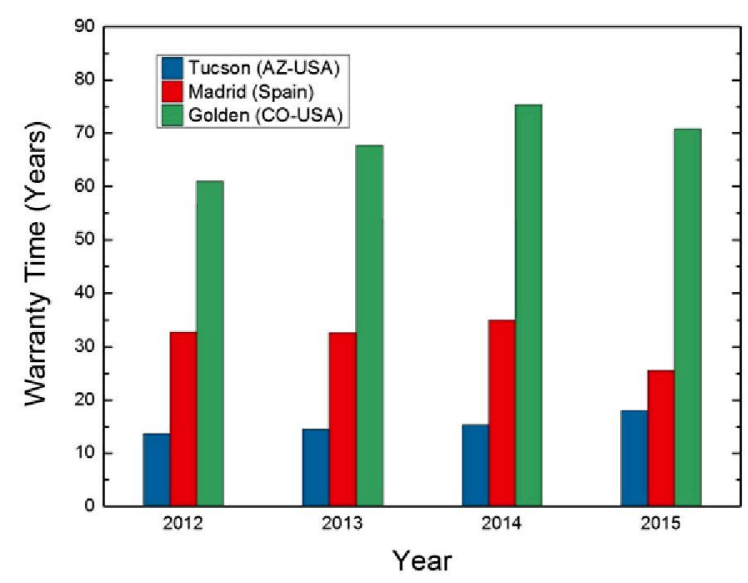

Figure 7. Warranty times of the concentrator photovoltaic module incorporating commercial triple junction solar cells (described in section 3) for different locations and years.

Table II. Warranty time for both $5 \%$ and $10 \%$ of failures in 2014 for Golden, Madrid and Tucson.

\begin{tabular}{ccc}
\hline Year 2014 & $\begin{array}{c}\mathrm{t}_{w} 5 \% \\
\text { (years) }\end{array}$ & $\begin{array}{r}\mathrm{t}_{w} \text { 10\% } \\
\text { (years) }\end{array}$ \\
\hline Golden (CO, USA) & 75.4 & 98.9 \\
Madrid (Spain) & 35.0 & 45.8 \\
Tucson (AZ, USA) & 15.3 & 20.0 \\
\hline
\end{tabular}

\section{DISCUSSION}

In section 3, we have applied the model to a specific case study (CPV module) for three locations and four years in order to show the most significant results of applying the model proposed in section 2. However, it is interesting to discuss the impact that the variation of some parameters of the case study (CPV module design) has in the results. This is why, in this section, we will analyse the influence of $R_{\text {th c_a }}$ (because it affects the solar cell temperature) and of $E_{\mathrm{a}}$ (because it affects to the reliability results and it relates with main failure mechanism in the solar cells).

\subsection{Influence of solar cell heat extraction}

It is well known that a reduction of the solar cell working temperature entails an improvement in reliability. There are several strategies to reduce the solar cell temperature in a CPV module, the most important being as follows:

- To reduce the thermal resistances, $R_{\mathrm{th} \_\mathrm{cm}}$ and $R_{\mathrm{th} \mathrm{m} \_\mathrm{a}}$ (Figure 1). The first case needs improvements in materials and in the thermal design of the solar cell assembly on the carrier and on the carrier packaging onto module, while the second case requires improvements of the thermal transference of module to the ambient. As an example of $R_{\text {th }}$ _a $_{-}$
Table III. Warranty time for $5 \%$ of failures in Tucson for four different years and two different rear flat plane thicknesses.

\begin{tabular}{ccc}
\hline Year & $\begin{array}{c}t_{w} 5 \% \text { (years) } \\
\text { for } 2 \mathrm{~mm}\end{array}$ & $\begin{array}{c}\mathrm{t}_{w} 5 \% \text { (years) } \\
\text { for } 4 \mathrm{~mm}\end{array}$ \\
\hline 2012 & 13.6 & 23.0 \\
2013 & 14.5 & 24.6 \\
2014 & 15.3 & 25.8 \\
2015 & 18.0 & 30.2 \\
\hline
\end{tabular}

improvement [16], a reduction of $3.7^{\circ} \mathrm{C}$ in the back module temperature was achieved in the same CPV module described in section 2 by replacing the $2 \mathrm{~mm}$ rear flat plate by a thicker one of $4 \mathrm{~mm}$. This entails a reduction from $R_{\text {th } \mathrm{m} \_\mathrm{a}(2 \mathrm{~mm})}\left(\frac{{ }^{\circ} \mathrm{C}}{\mathrm{W}}\right)=1.783-0.102 \cdot \mathrm{v}_{\text {wind }}$ to $R_{\text {th } \mathrm{m}_{-} \mathrm{a}(4 \mathrm{~mm})}\left(\frac{{ }^{\circ} \mathrm{C}}{\mathrm{W}}\right)=1.598-0.102 \cdot \mathrm{v}_{\text {wind }}$ (see Ref. [16] and 'Characteristics of the CPV module' in section 3). This thermal resistance reduction would result in an increase of the warranty time for the three locations (see e.g. the impact for Tucson in Table III). The estimated warranty times considering the whole period 2012-2015 are 118.1, 51.9 and 25.6 years for Golden, Madrid and Tucson respectively. However, that temperature reduction is not for free but impacts the cost of the CPV module and thus the LCOE. The trade-offs between reliability and costs are analysed in section 5 .

- To reduce the solar cell size implies a more homogenous heat distribution in the module because it improves the heat extraction, thus reducing the temperature increase with respect to ambient temperature for the same sun concentration [26,27]. The use of small solar cells allows to reduce costs in the heat dissipation, but, on the other hand, it requires an increase in the number of components and operations for the same module area that can increase the costs. This trade-off can be overcome if strategies like the LED-like manufacturing approach are used [28].

\subsection{Influence of activation energy}

A key parameter affecting the solar cell reliability is the activation energy of the main failure mechanism. A change of the energy activation value will entail different AF values as it has been shown in Figure 8. In order to analyse the influence of activation energy in warranty times, we have applied our model to activation energy values, namely, $0.9 \mathrm{eV}$ and $1.02 \mathrm{eV}$, obtained in previous works also for III-V solar cells $[9,11]$. The results are presented in Figure 8, which shows that warranty times decrease when activation energies increase. This is because high $E_{\mathrm{a}}$ values produce an $\mathrm{AF}$ increase and its influence on high temperatures has a big impact. This trend is always 


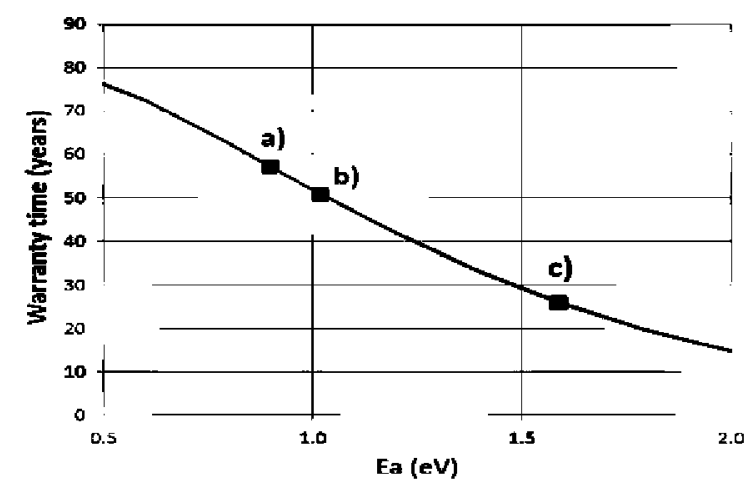

Figure 8. Influence of activation energy on warranty times. Three activation energies obtained in previous works. (a) $0.9 \mathrm{eV}$ [11], (b) $1.02 \mathrm{eV}$ [9] and (c) $1.59 \mathrm{eV} \mathrm{[10]} \mathrm{have} \mathrm{been} \mathrm{used}$ in the calculations.

qualitatively valid, but its quantification depends on the location and solar cell temperature histogram.

Therefore, if the failure associated with the front metal grid connection detected in the analysed solar cell [25] was mitigated or solved, the remaining failure modes (which did not have time for appearing in the ALT) will appear later on, thus resulting in a higher warranty time. In consequence, improved versions of these commercial solar cells will increase substantially the real warranty times.

\section{INFLUENCE ON THE LEVELISED COST OF ELECTRICITY}

The LCOE is defined as the cost of a unit of electricity in current monetary units. As a tool for system analysis, LCOE is particularly suitable, thanks to its projection of costs over the useful life of the system. It incorporates the normalised per $W_{p}$ initial investment or cost of the system $(C)$ and adds operation and maintenance costs (OM) over the system life cycle $(N)$. In order to obtain the total electricity output, the initial electricity generated by the system $(E)$ incorporates the available annual DNI and the alternating current (AC) system efficiency, while for the subsequent years, the annual decrease of the power of the CPV system because of degradation $(\epsilon)$. It then discounts the future revenue from the system to present values, reflecting inflation and costs of financing by means of the nominal discount rate $(d)[29]$ :

$$
\mathrm{LCOE}=\frac{C+\sum_{n=1}^{N} \frac{\mathrm{OM}_{n}}{(1+d)^{\mathrm{n}}}}{E \sum_{n=1}^{N} \frac{(1-\epsilon)^{\mathrm{n}}}{(1+d)^{\mathrm{n}}}}
$$

The LCOE is therefore calculated as a constant over the whole life of the system, expressed in $€ / \mathrm{kWh}$, $\$ / \mathrm{kWh}$, etc. Therefore, LCOE allows comparisons between costs of the electricity generated by different technologies. It contains more information than the system cost (expressed in terms of $€ / W_{p}, \$ / W_{p}$, etc.). All in all, it is the cost of energy that the end user is interested in, not the cost of the installed power.

Our choice for the nowadays values of the parameters influencing Eqn (8) is aligned with the approach described in Ref. [29]. The evolution of these nowadays values after a $1 \mathrm{GW}_{\mathrm{p}}$ cumulative installed power is also considered (Table IV). The life for a solar PV system is usually coincident with the manufacturer's guarantee period, which, in this paper [2,29], we assume as the warranty times presented in sections 3 and $4\left(N=t_{\mathrm{w}}\right)$. For the initial system cost, we assume the nowadays value of $€ 2.05 / \mathrm{W}_{\mathrm{p}}$ calculated in Ref. [27] for a $1 \mathrm{MW}_{\mathrm{p}}$ installation in the conditions of 2014 (1000x; module efficiency of $32.3 \%$ based on $40 \%$ efficient solar cells together with a benefit of $5 \%$ for the Engineering, Procurement and Construction Contractor). This value of $€ 2.05 / \mathrm{W}_{\mathrm{p}}$ could be below $€ 2 / W_{p}$ in 2016 , but it is difficult to quantify because of the lack of current accurate data. In LCOE calculations, further reductions in system cost down to $0.8 € / \mathrm{W}_{\mathrm{p}}$ achievable after $1 \mathrm{GW}_{\mathrm{p}}$ cumulative installed CPV capacity will be also taken into account.

Regarding OM cost, we have considered the expense of cleaning panels, replacing the inverter once during the system's lifetime and the tracker maintenance. The accuracy of $\mathrm{OM}$ cost data is not very high because of the relatively young companies producing CPV systems, and it will increase as experience grows. An assumption that is frequently made in the absence of meaningful operating data is that OM cost adds up to $2 \%$ [30] of the normalised per $W_{\mathrm{p}}$ initial investment cost, giving a figure in $€ / \mathrm{W}_{\mathrm{p}}, \$ / \mathrm{W}_{\mathrm{p}}$, etc., and is assumed to remain constant over time. Accordingly, we adopt an annual $2 \%$ for OM costs nowadays and $0.5 \%$ (which considers an improved and mature technology) after $1 \mathrm{GW}_{\mathrm{p}}$ cumulative installed capacity.

Table IV. Values for nowadays and after 1-GW cumulative installed concentrator photovoltaic (CPV) capacity in the levelised cost of electricity (LCOE) calculation assuming the data presented in Ref. [29].

\begin{tabular}{lllr}
\hline \multicolumn{1}{c}{ Parameter } & \multicolumn{1}{c}{ Symbol } & Nowadays & After $1 \mathrm{GW}$ \\
\hline Nominal discount rate & $d(\%)$ & 8 & 4 \\
Normalised-per-W, $W_{p}$ initial investment system cost & $C\left(€ W_{p}\right)$ & 2.05 & 0.8 \\
Normalised-per-W $W_{p}$ annual operation and maintenance cost* & $r(\%)$ & 2.0 & 0.5 \\
CPV system efficiency (alternating current, AC) & $\eta_{\mathrm{CPV}, \mathrm{AC}}(\%)$ & 26.8 & 30.5 \\
\hline
\end{tabular}

*This value should be interpreted as the percentage of $C$ that is spent on $\mathrm{OM}$ tasks on an annual basis. Therefore, $O \mathrm{M}_{\mathrm{n}}=r \mathrm{C}$ when using in Eqn (8). 
The choice of a discount rate value comes with ample uncertainty. The concept of discount rate puts a value on time preference on money, which varies by circumstance, location and the period considered. Besides, some investors vary their discount rate between PV technologies to reflect their perception of their financial risks. In this sense, CPV is discriminated against. Therefore, we have chosen $d=8 \%$ nowadays in comparison with a typical $4 \%$ for flat plate PV [31] that we assume after $1 \mathrm{GW}_{\mathrm{p}}$ cumulative capacity.

Regarding commercial module efficiency, we have considered for nowadays a current typical value of $32 \%$ as it was described in Ref. [29], while a value of $37 \%$ is expected to be reached well after $1 \mathrm{GW}_{\mathrm{p}}$ cumulative installed power. The whole CPV system efficiency (AC) is the result of applying a correcting factor of around $0.83-0.85$ to module efficiency (as a consequence of interconnection losses, module mismatch losses, tracking and wiring losses, high operating temperature and spectrum variations, soiling and, finally, $\mathrm{DC}-\mathrm{AC}$ conversion efficiency). Therefore, nowadays, the $32 \%$ module efficiency results in $26.8 \%$ system efficiency (AC), while it would increase till $30.5 \%$, thanks to the $37 \%$ efficient module after $1 \mathrm{GW}_{\mathrm{p}}$ cumulative installed power [29]. The summary of the assumed values is presented in Table IV.

Now, the specific values for each analysed location have to be determined. Firstly, the annual direct normal irradiation has been averaged at each location for the period of 2012 to 2015 . The warranty times presented in Table I have been also averaged for the same period and are assumed as the lifetime of the CPV system. These warranty times were calculated for the real CPV module having a rear plate thickness of $2 \mathrm{~mm}$ acting as passive heat sink. Finally, the improvement of the heat removal by increasing the rear plate thickness till $4 \mathrm{~mm}$ not only increases the warranty time (as described in section 4.1) but also increases $5 \%$ of the initial system cost. Again, the warranty times have been averaged for the 2012-2015 period. The summary of these values is presented in Table V.

Table V. Values for the lifetime of the concentrator photovoltaic (CPV) system ( $M$ and annual degradation rate of the CPV system efficiency $(€)$ for Golden, Madrid and Tucson.

\begin{tabular}{lccrc}
\hline Place & $\begin{array}{c}\text { Annual DNI } \\
\left(\mathrm{kWh} / \mathrm{m}^{2}\right)\end{array}$ & $\begin{array}{c}\text { Rear plate } \\
\text { thickness }(\mathrm{mm})\end{array}$ & $\begin{array}{c}N \\
\text { (years) }\end{array}$ & $\begin{array}{r}€(\%) \\
\text { year) }\end{array}$ \\
\hline Golden & 1951 & 2 & 68 & 0.129 \\
(CO, USA) & & 4 & 118 & 0.074 \\
Madrid & 2007 & 2 & 31 & 0.282 \\
(Spain) & & 4 & 52 & 0.168 \\
Tucson (AZ, & 2642 & 2 & 15 & 0.583 \\
USA) & & 4 & 26 & 0.336 \\
\hline
\end{tabular}

The annual direct normal irradiation (DNI) is the average for the 20122015 period. For each place, two thicknesses of the rear plate of the modules producing different warranty times are considered according to section 4.1 .
The results of the LCOE calculations are shown in Figure 9. As can be seen, nowadays, the LCOE of $€ \mathrm{c} 10-12 / \mathrm{kWh}$ can be achieved for the three locations that are competitive with the LCOEs achieved by silicon flat plate systems in sunny locations for residential and commercial segments $[29,32,33]$. The LCOEs achieved in Madrid and Golden are very similar, showing that the huge lifetime of the CPV systems in Golden does not strongly impact LCOE because future revenue from the system to present values is discounted to reflect inflation and costs of financing. Besides, we have assumed for the OM cost the inverter's replacement once during the system's lifetime, while more replacements seem necessary for lifetimes longer than 30 years (as the cases of Madrid and Golden), thus increasing the LCOEs presented in Figure 9 (top). Consequently, the better heat extraction achieved by using a $4 \mathrm{~mm}$ rear plate in the module does not produce a significant LCOE reduction in Madrid and even an increase for Golden. On the contrary, the use of a $4 \mathrm{~mm}$ rear plate in the module results in an LCOE reduction from 11.6 to $9.9 € \mathrm{c} / \mathrm{kWh}$ in Tucson, thanks to a lifetime increase from 15 to 26 years respectively. In this situation, the higher DNI of Tucson drives the cost reduction when comparing with Golden and Madrid.

After $1 \mathrm{GW}_{\mathrm{p}}$ cumulative installed power, CPV will be a very mature technology having similar discount rates $(4 \%)$
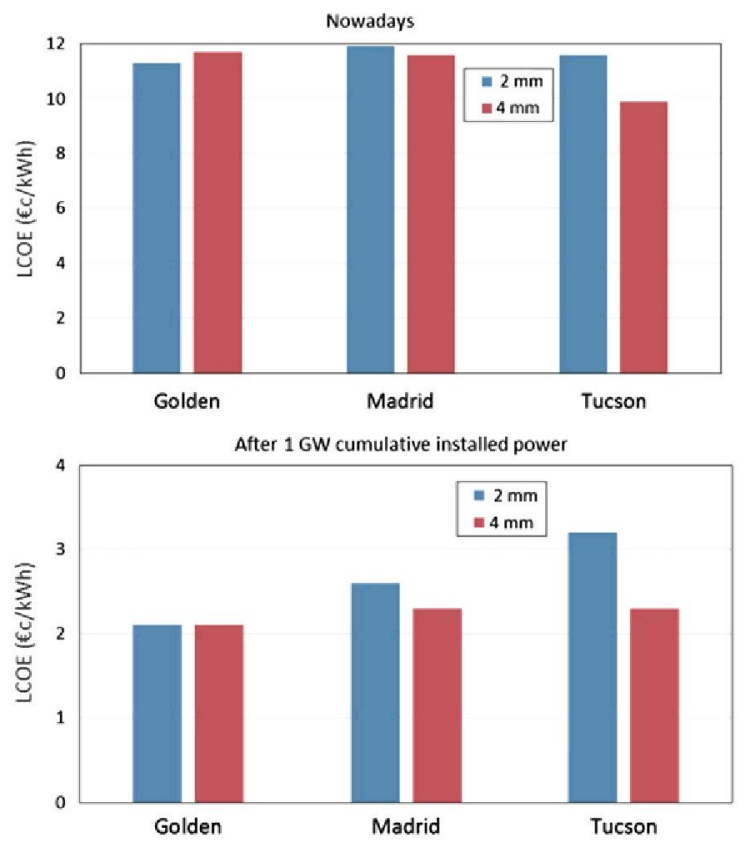

Figure 9. Levelised cost of electricity calculations for nowadays (top) and after $1 \mathrm{GW}_{\mathrm{p}}$ cumulative installed concentrator photovoltaic power (bottom). Thicknesses of $2 \mathrm{~mm}$ and $4 \mathrm{~mm}$ of the rear side of the modules (section 4.1) and parameters of Tables IV and $V$ have been used. 
and system cost $\left(€ 0.8 / \mathrm{W}_{\mathrm{p}}\right)$ than those of silicon flat module systems and even better performance in aspects such as degradation rate and system life (Tables IV and V). In this scenario, a dramatic LCOE reduction to levels of $\epsilon_{\mathrm{c} 2}$ $3 / \mathrm{kWh}$ is expected (Figure 9, bottom). Now, the influence of a high DNI is counterbalanced by longer system lifetimes; thus, the increase of the rear plate thickness till $4 \mathrm{~mm}$ has sense for Tucson and Madrid. The low impact that DNI has in this scenario would suggest that CPV systems could be cost competitive also in regions with moderate DNI. In fact, the grid parity is envisaged for places with annual DNI of $1000 \mathrm{kWh} / \mathrm{m}^{2}$ such as Central Europe, North of USA and most part of Canada [29].

\section{SUMMARY AND CONCLUSIONS}

A methodology to evaluate the reliability parameters for CPV solar cells in real applications based on temperature ALT results has been presented. Although the model can be applied for any reliability parameter evaluated in ALT, we have applied this procedure for the evaluation of warranty times of a type of commercial triple junction solar cells operating inside real CPV modules in Golden, Madrid and Tucson for the period 2012-2015. Main conclusions of the work are as follows:

- In order to assess the reliability function and all the related parameters in real applications, based in temperature ALT results, it is necessary to consider the instantaneous atmospheric data (irradiance, ambient temperature and wind speed), and not the average ones. This is because reliability parameters are strongly influenced by the highest solar cell temperature values that are hindered by average values.

- Mean solar cell temperature is not a representative value for reliability parameter assessment because it does not consider the large influence of high solar cell temperature values in reliability. In order to solve this problem, we have defined the equivalent time at $80^{\circ} \mathrm{C}$ of the solar cell temperature as a reliability representative time that takes into account the influence of the temperature in the reliability.

- The influence of the selected year for a specific location is lower than the location influence.

- The influence of the location on the reliability of solar cells is huge. Therefore, it has no sense to supply general reliability values. Comparing the two extreme analysed cases in 2014, there is a ratio of five in the warranty times between Golden (Colorado, USA) and Tucson (Arizona, USA), namely, 75 and 15 years respectively.

- Warranty times in Golden and Madrid, namely, 68 and 31 years for the analysed period respectively, indicated the suitability of the analysed design for its operation in these locations, thus demonstrating the robustness of CPV solar cells. Nevertheless, the warranty time of 15 years for Tucson is not enough for photovoltaic applications, suggesting the need of improvement of the CPV module. Replacing rear flat plane of $2 \mathrm{~mm}$ by other thicker, $4 \mathrm{~mm}$, the warranty times in Tucson increase significantly, up to more than 25 years.

- Based on the previous conclusion, it could be necessary to consider the possibility to use different thermal designs of the CPV system, depending on the location. In order to do this, we have discussed the influence of improving the heat removal and the reduction of the solar cell size.

- Improved versions of the analysed triple junction commercial solar cells will increase substantially the real warranty times.

- LCOE of $€ \mathrm{c} 10-12 / \mathrm{kWh}$ can be achieved nowadays for the three locations that are competitive with the LCOEs achieved by silicon flat plate systems in sunny locations.

- The use of a specific module heat extraction design for highly DNI places with extreme high temperatures such as Tucson is required.

- After $1 \mathrm{GW}_{\mathrm{p}}$ cumulative installed power, CPV will be a very mature technology, resulting in a dramatic LCOE reduction to levels of $€_{\mathrm{c}} 2-3 / \mathrm{kWh}$ for Golden, Madrid and Tucson. Places with much lower DNI such as central Europe, Canada and north of USA would be also suitable places for producing CPV electricity with a competitive LCOE.

The results obtained, like any other derived from the reliability determination of a given product, are relevant to the specific type of solar cells and modules analysed in this paper, although the obtained trends are of general application.

\subsection{Glossary of Terms}

- AF: Acceleration factor. Factor that is accelerated the life of a device with respect nominal conditions due the stress applied in an accelerated life test.

- $\mathrm{AF}_{\mathrm{T} \text { cell/80 }}$ : Acceleration Acceleration factor of a temporal reliability parameter (i.e. warranty and mean time to failure) due the solar cell temperature is $T_{\text {cell }}$ with respect to $80{ }^{\circ} \mathrm{C}$ solar cell temperature.

- ALT: Accelerated life test. Is a test where a working device is subjected to conditions higher than normal service parameters in order to accelerate the failures times with the objective to assess the life parameters in a short period of time.

- Arrhenius equation: From a reliability point of view gives the basic relationship between the rate at which a failure mechanism occurs, the temperature and the activation energy of the failure mechanism.

- $C$ : Normalised per $\mathrm{W}_{\mathrm{p}}$ initial investment or cost of the system.

- D: Nominal discount rate. 
- $E$ : Initial electricity generated by the CPV system.

- $E_{\mathrm{a}}(\mathrm{eV})$ : Activation energy, defined as the minimum amount of energy required to initiate a particular process. It is used in order to assess temperature AF in Arrhenius model.

- Equivalent time at $80^{\circ} \mathrm{C}$ : Time at $T_{\text {cell }}$ is extrapolated to equivalent time at $80^{\circ} \mathrm{C}$ multiplying the real time by $\mathrm{AF}_{\mathrm{T}_{\mathrm{cell}} / 80}$. From reliability point of view will be the equivalent time at $80^{\circ} \mathrm{C}$.

- $k$ : Boltzmann constant. It is used in order to assess temperature AF in Arrhenius model

- $n$ : Years for a given calculation of LCOE.

- $N$ : Life cycle of the CPV system.

- OM: Operation and maintenance costs.

- $R_{\mathrm{th}}$ : Thermal resistance. The thermal resistance $\left(R_{\mathrm{th}}\right)$ is defined as the rate of temperature increase $(K)$ for the dissipated power (W). It is a measure of the capability of the material to dissipate heat.

- $R_{\text {th c_m }}$ : Thermal resistance between solar cell and module

- $R_{\mathrm{th} \text { m_a }}$ : Thermal resistance between module and ambient.

- Solar cell mean temperature: Mean value of solar cell temperature. This value does not consider the important influence of higher solar cell temperature in reliability.

- Solar cell mean temperature at $80{ }^{\circ} \mathrm{C}$ equivalent time, $T_{\text {eqMean }}\left({ }^{\circ} \mathrm{C}\right)$ : Mean value of solar cell temperature when times are extrapolated to equivalent time at $80^{\circ} \mathrm{C}$. This value considers the important influence of higher solar cell temperature in reliability. This value does not depend on the selected reference temperature.

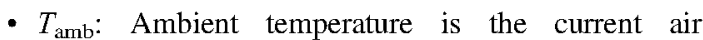
temperature, the overall temperature of the outdoor air that surrounds us.

- $T_{\text {cell }}$ : Solar cell temperature is the junction solar cell temperature. It depends on climatic conditions (ambient temperature, irradiance and wind velocity) and solar cell design (thermal and electrical performance).

- Instantaneous solar cell temperature. Solar cell temperature in an instant of time.

- Hourly average solar cell temperature. Average solar cell temperature during $1 \mathrm{~h}$.

- Average daily temperature. Average solar cell temperature during 1 day.

- $T_{\text {ref }}$ : Reference temperature. This temperature is selected as reference for reliability results of ALT. In conventional applications, environmental conditions are controlled, are easily assessed and are usually called nominal temperature at nominal working conditions. In devices that work in uncontrolled environmental conditions, the assessment is much more complex.

- $t_{\text {eq }, 80^{\circ} \mathrm{C}}\left(\frac{\text { hours }}{\text { year }}\right)$ : Yearly-equivalent time at $80^{\circ} \mathrm{C}$ from the reliability point of view. Real times are multiplied by acceleration factor of solar cell temperature with respect $80^{\circ} \mathrm{C}$.

- $t_{\mathrm{w}}$ (years): Warranty time in this paper is the time in years at which $5 \%$ of solar cells have failed. It is a ratio between warranty time at reference temperature (i.e. $80^{\circ} \mathrm{C}$ ) in hours, obtained as a result of the ALT, $t_{\mathrm{w}, 80^{\circ} \mathrm{C}}$ (hours) and yearly equivalent time at the same reference temperature, $t_{\mathrm{eq}, 80^{\circ} \mathrm{C}}\left(\frac{\text { hours }}{\text { year }}\right)$. It does not depend on reference temperature; see Eqn (7) of the main paper.

- $t_{\mathrm{w}, 80^{\circ} \mathrm{C}}$ (hours): Warranty time in this paper is the time in hours at which $5 \%$ of solar cells at $80^{\circ} \mathrm{C}$ have failed. It is obtained from ALT.

- $\epsilon$ : Power degradation of the CPV system.

\section{ACKNOWLEDGEMENTS}

This work has been supported by the Spanish MINECO through the projects TEC2014-54260-C3-1-P and PCIN2015-181-C02-02 and by the Comunidad de Madrid through the project MADRID-PV (S2013/MAE-2780). Thanks to Rubén Núñez for the complementary explanations of his work [16] and for maintaining and delivering the information of the solar station of Instituto de Energía Solar, Universidad Politécnica de Madrid (Madrid, Spain). Thanks to NREL (National Renewable Energy Laboratory) Measurement and Instrumentation Data Center (MIDC) (https://www.nrel.gov/midc/); the Observed Atmospheric and Solar Information System (OASIS), Tucson, Arizona (data); and the Solar Research Radiation Laboratory BMS of the NREL Solar Radiation Research Laboratory, Golden, Colorado (data).

\section{REFERENCES}

1. Jean J, Brown PR, Jaffe RL, Buonassisi T, Bulović V. Pathways for solar photovoltaics. Energy \& Environmental Science 2015; 8(4): 1200-1219. https://doi.org/10.1039/C4EE04073B.

2. Algora C, Rey-Stolle I (Eds). Handbook of Concentrator Photovoltaic Technology. John Wiley \& Sons, Ltd: Chichester, West Sussex, United Kingdom, 2016.

3. S. Philipps, A. Bett, K. Horowitz and S. Kurtz. Current status of concentrator photovoltaic (CPV) technology. Fraunhofer Institute ISE/NREL 2016 TP-6A20-63916.

4. T. Zech, T. Gerstmaier, M. Röttger, R. Moretta, C. Braun, A. Gombert, M. Steiner, G. Siefer, D. Sánchez, $O$ de la Rubia and M. Martinez, "Return of experience from 5 years of field data: long term performance reliability of Soitec's CPV technology", Proc. Of the 29th European PV Solar Energy Conference and Exhibition, Sep 22th-26th, Amsterdam (Netherlands), 
p. 2017-2019 (2014). https://doi.org/10.13140/2.1. 2992.4164.

5. Algora C, Espinet P, Vázquez M, Bosco N, Miller D, Kurtz S, Rubio F, McConnell R. Reliability. In Handbook of Concentrator Photovoltaic Technology, Algora C, Rey-Stolle I (edss), Chapter 9. John Wiley \& Sons Ltd: West Sussex, UK, 2016.

6. Bosco N, Silverman T, Kurtz S. Climate specific thermomechanical fatigue of flat plate photovoltaic module solder joints. Microelectronics Reliability 2016; 62: 124-129. https://doi.org/10.1016/j.microrel. 2016.03.024.

7. Kurtz S, Whitfield K, TamizhMani G, Koehl M, Miller D, Joyce J, Wohlgemuth J, Bosco N, Kempe M, Zgonena T. Evaluation of high-temperature exposure of photovoltaic modules. Progress in Photovoltaics. Research and Applications 2011; 19: 954-965. https://doi.org/10.1002/pip.1103.

8. Pan R, Kuitche J, Tamizhmani G. Degradation analysis of solar photovoltaic modules: influence of environmental factor. Reliability and Maintainability Symposium, RAMS 2011. https://doi.org/10.1109/ RAMS.2011.5754514.

9. Núñez N, González J, Vázquez M, Algora C, Espinet $\mathrm{P}$. Evaluation of the reliability of high concentrator GaAs solar cells by means of temperature accelerated aging tests. Progress in Photovoltaics: Research and Applications 2013; 21: 1104-1113. https://doi.org/ 10.1002/pip. 2212.

10. Espinet-González P, Algora C, Núñez N, Orlando V, Vázquez $\mathrm{M}$, Bautista $\mathrm{J}$, Araki $\mathrm{K}$. Temperature accelerated life test on commercial concentrator III-V triple-junction solar cells and reliability analysis as a function of the operating temperature. Progress in Photovoltaics: Research and Applications 2015; 23: 559-569. https://doi.org/10.1002/pip.2461.

11. González JR, Vázquez M, Núñez N, Algora C, ReyStolle I, Galiana B. Reliability analysis of temperature step-stress tests on III-V high concentrator solar cells. Microelectronics Reliability 2009; 49: 673-680. https://doi.org/10.1016/j.microrel.2009.04.001.

12. Andreas, A.; Stoffel, T.; NREL Solar Radiation Research Laboratory (SRRL): Baseline Measurement System (BMS); Golden, Colorado (data). NREL Report No. DA-5500-56488. 1981. https://doi.org/ 10.7799/1052221.

13. Andreas, A.; Wilcox, S. Observed Atmospheric and Solar Information System (OASIS); Tucson, Arizona (data); 2010, NREL Report No. DA-5500-56494. https://doi.org/10.7799/1052226.

14. Almonacid F, Pérez-Higueras P, Fernández E, Rodrigo P. Relation between the cell temperature of a HCPV module and atmospheric parameters. Solar Energy
Materials and Solar Cells 2012; 105: 322-327. https://doi.org/10.1016/j.solmat.2012.06.043.

15. Fernández E, Almonacid F, Rodrigo P, Pérez-Higueras P. Calculation of the cell temperature of a high concentrator photovoltaic (HCPV) module: a study and comparison of different methods. Solar Energy Materials and Solar Cells 2014; 121: 144-151. https://doi.org/10.1016/j.solmat.2013.11.009.

16. R. Nuñez, I. Antón, S. Askins, G. Sala, and K. Araki. Characterization of CPV arrays based on differences on their thermal resistances, in 10th International Conference on Concentrator Photovoltaic Systems (CPV-10), Albuquerque, NM (USA), 2014, 144-148. https://doi.org/10.1063/1.4897048.

17. Arrhenius S. Über die Reaktionsgeschwindigkeit bei der Inversion von Rohrzucker durch Säuren. Zeitschrift fü Physikalische Chemie 1889; 4: 226-248.

18. Sorensen N, Thomas E, Quintana M, Barkaszi S, Rosenthal A, Zhang Z, Kurtz S. Thermal study of inverter components. IEEE Journal of Photovoltaics 2013; 3(2): 807-813. https://doi.org/10.1109/ JPHOTOV.2013.2244162.

19. Lall P. Tutorial: temperature as an input to microelectronics-reliability models. IEEE Transactions on Reliability 1996; 45: 3-9. https://doi.org/10.1109/ 24.488908.

20. Parry J, Rantala J, Lasance C. Enhanced electronic system reliability - challenges for temperature prediction. IEEE Transactions on Components and Packaging Technologies 2002; 25: 533-538. https:// doi.org/10.1109/TCAPT.2002.808001.

21. Narendran N, Gu Y. Life of LED-based white light sources. Journal of Display Technology 2005; 1: 167-171. https://doi.org/10.1109/JDT.2005.852510.

22. E. Hong and N. Narendran. A method for projecting useful life of LED lighting systems in Optical Science and Technology, SPIE's 48th Annual Meeting, International Society for Optics and Photonics, 2004 , pp. 93-99. https://doi.org/10.1117/12.509682

23. D. W. Colt and M.G. Priore. Impact of nonoperating periods on equipment reliability. RADC-TR85-91. Rome Air Development Center RADC. 1985.

24. Nuñez N, Vazquez M, Orlando V, EspinetGonzález P, Algora C. Semi-quantitative temperature accelerated life test (ALT) for the reliability qualification of concentrator solar cells and cell on carriers. Progress in Photovoltaics: Research and Applications 2015; 23: 1857-1866. https://doi.org/ 10.1002/pip.2631.

25. Orlando V, Gabás M, Galiana B, Espinet-González $P$, Palanco S, Nuñez N, Vázquez M, Araki K, Algora C. Failure analysis on lattice matched $\mathrm{GaInP/Ga(In)As/}$ Ge commercial concentrator solar cells after 
temperature accelerated life tests. Progress in Photovoltaics: Research and Applications 2017; 25: 97-112. https://doi.org/10.1002/pip.2818.

26. Algora C. Very-high-concentration challenges of III$\mathrm{V}$ multijunction solar cells ch.5. In Concentrators Photovoltaics, Luque A, Andreed V (edss). Springer: Berlin Heidelberg, 2007.

27. García I, Victoria M, Antón I. Temperature effects on CPV solar cells, optics and modules ch. 5. In Handbook of Concentrator Photovoltaic Technology, Algora C, Rey-Stolle I (edss). John Wiley \& Sons Ltd: West Sussex, UK, 2016.

28. C. Algora, I. Rey-Stolle, B. Galiana, J.R. Gonzalez, M. Baudrit and I. García. Strategic options for a LED-like approach in III-V concentrator photovoltaics in Proceedings IEEE 4th World Conference on Photovoltaic Energy Conversion. 2006, 741-744. https://doi.org/10.1109/WCPEC.2006.279562.
29. Algora C, Talavera DL, Nofuentes G. Cost analysis. In Chapter 14 in Handbook of Concentrator Photovoltaic Technology, Algora C, Rey-Stolle I (edss). John Wiley \& Sons Ltd: West Sussex, UK, 2016.

30. A. Extance and C. Marquez. The concentrated photovoltaics industry report. CPV Today 2010.

31. Kost C, Mayer JN, Thomsen J, Hartmann N, Senkpiel C, Philipps S, Nold S, Lude S, Saad N, Schlegl T. Levelized Cost of Electricity Renewable Energy Technologies. Fraunhofer ISE Study: November, 2013.

32. E. Vartiainen, G. Masson, C. Breyer, PV LCOE in Europe 2015-2050, Proceedings of the 31st European Photovoltaic Solar Energy Conference, September 14-18, 2015, Hamburg, Germany https:// doi.org/10.4229/31stEUPVSEC2015-7DO.15.1

33. Lazard, Lazard's levelized cost of energy analysis version 10.0, December 2016, www.lazard.com. 